Jelena Šesnić

University of Zagreb

\title{
F. O. Matthiessen, C. L. R. James and a Sense of the Past of American Studies
}

\section{Introduction $^{1}$}

T became clear during one of the sessions at the 2015 ACLA conference in Seattle, Washington, that a revival was under way of some aspects of Cold War American Studies. The three-day session, entitled "Americanist Criticism, Back and Forward," featured presentations on, among others, the luminaries of American Studies of all time, so to speak, offering a reassessment of F. O. [Francis Otto] Matthiessen and Sacvan Bercovitch (twice), and considering in a separate but related presentation the impact of institutional and government-backed programs of academic exchange during and after the Cold War. ${ }^{2}$ While the trend itself-that of occasionally folding back upon itself and self-consciously assessing its own methods and their scope and impact—has from the beginning informed the discipline of American Studies, it still struck me as an uncanny occasion to witness how the discipline had retrieved, and in the process revised and rewrote, its own past. ${ }^{3}$ The session, in its choice of themes framed by a singular historical event, auspicious for the emergence of the discipline, if not quite for the world - the Cold War itself—as well as by its choice of featured scholars, offered contested readings and challenging interpretations of the period.

According to Phillip Wegner's term, 1989 and the fall of the Berlin War ushered in "the long nineties" (8-9) while it tasked literary historians and Americanists with revising the discipline's investment in its own ideological foundations, a task that continues to this day. Alan Wald's study of the period that concerns me here, the beginning of the Cold War, provides a stalwart example of what attends the literary historian's task when he claims: "To be alive in the early twenty-first century is to live in the residue of mixed inheritances of the postwar era; we do not have an option to be unentangled in this lost time" (xiii). ${ }^{4}$ Insofar as the New Americanists (the

\footnotetext{
The writing of the essay was supported by the Croatian Scientific Foundation grant (HRZZ-1543), which I gratefully acknowledge. I would like to thank also the J.F. Kennedy Center library at the Free University in Berlin for a library grant which facilitated my research.

2 Information on the full session is available in the conference program "ACLA 2015," Unversity of Washington, Seattle, March 26-29, 2015.

3 The trend is testified to, for instance, by browsing the archive of the official journal of the ASA, The American Quarterly. Ever since its earliest issues, the journal has registered major methodological innovations and offered periodical assessments of the state of the discipline.

4 In the context of European and Croatian American Studies in particular, recent contributions by Stipe Grgas evince the same tendency of stock-taking in the discipline and extrapolating future trends therefrom.
} 
term was initially redolent of censure and irony) were among the first and most eager critical coterie to take up the assignment, it was their turn to invent or delineate what one of their most outstanding members, Donald Pease, has termed a new "field imaginary" (Pease 1990). Having now witnessed several waves of the said revision business, we might want to consider some of the ways in which each new generation of American Studies scholars approaches and assesses, as if holding a mirror to itself, the key, originating moment of the founding of a full-fledged study of national literature, culture, civilization, and nation-state (all major topics in American Studies). Simultaneously, it means going down the time lane towards the early phase of the Cold War. ${ }^{5}$

While no Americanist would be justified in discounting the contributions of either Matthiessen or, later, Bercovitch, this unequivocal recognition of their respective commendable services rendered to the discipline further obligates us to inquire as to what attitude these two outstanding scholars of American Studies in their respective periods held in relation to the Cold War context, which in the case of Matthiessen was only beginning to engross his work, whereas in the case of Bercovitch was followed on its final course and seen to its historical end. And consequently, what lessons might their insights bequeath to us in the present time and for the current state of American Studies? I will only briefly suggest the closing perspective that was cast on the Cold War by Bercovitch, whose work made an elegant, informed and canny transition from the Cold-War to the post-Cold-War state, even if some recent readers of his work still fault him for participating in and reinforcing the so-called "liberal consensus" paradigm (Pease 1990: 19-23). However, even an overview of Bercovitch's critical concerns ought to allow us to consider the term "liberal" in its positive and potent articulation, and not simply as a stale political option maligned by the New Americanists eager to break a new path in the wake of the major re-alignment of the discipline in 1989, as the Cold War ended (Fuller 122-46).

\footnotetext{
Grgas's informed reflections are further solidified by his more recent sorties outside of the strict literary and cultural boundaries of the section of American Studies overlapping with the humanities and branching out into adjacent fields of social sciences leading him into veritable interdisciplinarity. To this one must add his displaced position as a non-U.S. Americanist. As Matthiessen will point out in his text considered here, it took his voyage to Europe for him to fully understand the implication of being American at the time $(F H E, 3)$. Also, as he came to realize at the end of the journey, the civilization that bred him and his humanistic profession, including his auspicious "invention" of American Renaissance, faced a death threat (FHE, 194). So much about the benefits (and risks) of a displaced vision. Cf. Grgas 2013; Grgas 2014; Grgas 2015a; Grgas 2015b.

5 This is done, for instance, by one of the old guard, Leo Marx, who reminds us of the discipline's relative youth allowing one to discern the "laying on of hands" in the profession since it is the case that Marx, himself occupying a middle ground between the prevailing liberal consensus paradigm (up until its fracturing in the 1970s), the emergence of the New Left in the 1960s, and the tide of new approaches hailed by the theoretical revolution of the 1970s and 1980s, was Matthiessen's student at Harvard, as were several other key representatives of early- to mid-Cold War studies: for instance, Henry Nash Smith and R.W.B. Lewis (Marx; Pfister 8.)
} 
My focus will rather be on the kind of errant labor that humanistic inquiry was required to perform at the very outset of the Cold War, at the time when Matthiessen reached his full maturity as a scholar and critic of American literature and culture, but also a period fraught with political anxiety and animosity that would soon divide the world into two separate ideological camps, East and West, or totalitarian/communist and democratic/capitalist (cf. President Truman's 1951 State of the Union Address [Truman]). Matthiessen was hardly the only scholar and critic to have faced what might have seemed an impossible choice requiring of him to succumb to the debilitating and, ultimately, humiliating absolutist logic of the Cold War; the other conspicuous instance of an intense and courageous intellectual engagement that on one hand transmuted into a personal ethical stance while, on the other, provided a penetrating scrutiny of the very logic and meaning of the discipline in a changing world, is presented by C. L. R. [Cyril Lionel Robert] James, particularly in his capacity as the author of a full-scale study of Herman Melville, Mariners, Renegades and Castaways: The Story of Herman Melville and the World We Live In. I will first outline the dilemmas attending Matthiessen's position and will then move on to consider James's perspective in the same period, all the while claiming that their highly idiosyncratic books might be illustrative of the entire stretch of American Studies development so far.

In his study of the continuity and vitality of Emersonian criticism, Randall Fuller makes a general statement as to the greater purpose of American Studies in particular and the humanities in general in the United States, which are to confront "the challenges of modernity manifested in history" (4). If we stay with this thought, then it proceeds that "particular acts of cultural and literary criticism might feel urgent at a given time" (Fuller 4). We shall see how Matthiessen was immersed in the sense of a particular mission that, as an American academic, a literature professor, he might have had for his both wistful and downbeat student audiences in Europe. In the case of his contemporary C. L. R. James, the sense of urgency not only moves him to write the text discussed here, but at some point towers over all the other themes.

\section{The European Other in the Founding of American Studies}

The dilemma that Matthiessen faced, together with a host of his intellectual companions in the United States, was contingent on his already canonical status in the fledgling field of American Studies that he earned with his 1941 text American Renaissance. The book in that particular historical moment not only summarized in a forceful way what his predecessors were already expressing about antebellum America (roughly from the 1830 s to the 1850s), but also effectively created one of the key terms for understanding the literature of post-revolutionary and antebellum American society, and in the process appraised all the previous and subsequent developments by the measuring rod established by Matthiessen for the said period. Still, as Eric Cheyfitz points out from his revisionist perspective, at that point in time the canonization of Matthiessen's work was not an obvious development but the result of "a complex cultural machinery" operating in American literary history, which is to say, Cheyfitz intones, that rather than the 
beginning, the book marked the end of the process of establishing a new literary canon (349) — a canon, one might add, fit for the American century that reached its zenith.

In a book written as the United States was entering the war against fascism and nazism on a global scale, Matthiessen could develop his political inclinations with a progressive, socialist, and leftist bent and weave them into a greater narrative of his country as a nation standing for those same qualities, a contention that would hardly be an overstatement in the context of the American 1930s and 1940s. Immediately after the war's end, there was still a period of a couple of years (at least until early 1947) in which a certain wavering in politics was tolerated, since it was by no means clear that the new world order would come about in a relentless competition between the two emergent superpowers, the United States and the Soviet Union.

It is therefore exciting, as well as instructive, to consider precisely that period of vacillation which marked the later phase of Matthiessen's critical, academic, and political work addressed in his underappreciated memoir/travelogue From the Heart of Europe (1948). However, given the discipline's current vicissitudes, it is no surprise that the text is being recovered and re-incorporated into the Matthiessen canon. Following upon my initial question, one needs to address a sense of the past that infused this personal account of Matthiessen's public engagements when the world was still "ripe for a new beginning." The lesson obviously intended by Matthiessen for his English-speaking audience was soon lost upon them, since the book had been rendered obsolete and almost utopian even by the time it was published. In 1948, the Cold War had already descended upon the world, so that the message that might have resonated for Matthiessen's students in the seminars and lectures that he held in Europe would no longer reach the ears of those left "behind the iron curtain" (as in Churchill's famous and provocative speech [Churchill]), while for others it will be branded for its wavering over settled points of American domestic and foreign policies in their pursuit of the Cold War (an instance of scathing criticism of Matthiessen's position is provided by Fuller $176 \mathrm{n} 63$ ). So even before the book could have gained a life of its own, it was made a victim of a new ideological conflict. However, that it deserves to be rediscovered, having come towards the end of Matthiessen's long career thus serving as his testament in symbolic and, sadly, real terms, is testified by Art Redding's apposite assessment: "At the heart of Matthiessen's lifelong critical project was an overwhelming sense of the need for each generation to critically 'repossess' the past, coupled with an obsessive concentration on love and politics" (39). This is further glossed in Fuller's remark on Emerson that equally well applies to Matthiessen's work and impact: "As a practitioner of the literary, he aspired to provoke aesthetic transformation by summoning public feeling and mobilizing affect as well as thought" (7). In the remainder of the discussion in this section it is my aim to register some ways that spurred Matthiessen's repossession of the discipline's past, which is rightly considered symbiotic with his own personal destiny. ${ }^{6}$

6 This was one of Matthiessen's last published works during his life, which ended in suicide in 1950. Subsequently, additional material authored by him was made available. For an elaboration of the way Matthiessen interwove the public and the private cf. Arac; Grossman; Redding. 
My contention will be that the retrieval of any (forgotten, suppressed, or repressed) document necessarily reshapes the past(s) contained in a historical archive, the case being that this precarious yet imperious role of the archive cannot obviate the incessant inclusion, exclusion, or rearrangement of the items in its fold. ${ }^{7}$ Therefore, the long neglected (or understudied) texts by Matthiessen and James should be seen as an occasion to return to the near beginnings of the discipline of American Studies, and thus to recast not only Matthiessen's academic fate, but also that of the entire intellectual endeavor to which he had contributed. In other words, the past of American Studies is significantly and instructively revised if we attend to Matthiessen's 1948 account of an American Studies seminar in a Europe devastated by the massive armed conflict and on the verge of entering another period of consequential tension. Matthiessen's text is thus an intellectual record, an account which spells for us the personal and professional sacrifice that the Cold War would soon be exacting from its unwitting participants. Simultaneously, Matthiessen is correct in assessing that his personal, even intimate ruminations must be made public and placed in the context of his entire life and career. In his travelogue/memoir he strategically blends and intertwines the public and the private (so unlike his critical studies proper) in order to make a case for a free, democratic, and popular American Studies practice. Let us see how he proposed to carry the discipline to its new stage, to which it could not ascend at the time.

From the Heart of Europe is a first-person account of F. O. Matthiessen's participation in the first in a long series of Salzburg seminars on American Studies extending to this day. In addition to providing a sort of intellectual diary of his academic engagement, Matthiessen spiced the book with plentiful comments on his itineraries in Central Europe before and after the seminar itself took place (Germany, Austria, Czechoslovakia, and Hungary). The period encompassed in his multifaceted book extends from July to December of 1947 , while the book (not insignificant for our discussion) came out in 1948, just after the communist coup in Czechoslovakia, marking just one step along the way to Cold War entrenchment. This is to say that the book literally stands at the juncture of two eras signaling the full installment of the post-war geopolitics. What was in the balance for Matthiessen in writing this book is no less the fate of the discipline that simultaneously mirrored the fate of Europe at the time.

For Matthiessen, an American coming to a Europe devastated by war, the fact of "spiritual depression" is salient and so unlike the American brash self-confidence (4). ${ }^{8}$ Even France must allow itself to become overshadowed by America in the field of culture, a fact that attests to the cultural ascension of America, its shedding of its postcolonial status. In a distinct but related context, Harry Levin complacently noted that the hegemonic role of American culture in Europe was inevitable since it was backed

For a recent specific illustration of the role of archive in American Studies, cf. Lazo.

8 All subsequent references from the text of From the Heart of Europe will be provided parenthetically in the text. 
up by the then unfolding Marshall Plan (264-65). ${ }^{9}$ Certainly, the fact that the war had just been won by two non-European powers, the USA and the USSR, sent a clear message that Europe had been removed from center stage. Matthiessen himself enacts a counter-missionary move, now coming to "proselytize" in Europe, which apparently must be re-taught its own cultural legacy. An enthusiastic group of Harvard students, some of them tracing their recent European roots, had come up with an idea to bring together a number of European students and young professionals, hopefully from both Eastern and Western Europe, guided by the notion that American Studies could be a rallying point for the divided and scarred Europeans, since it was, in Henry Nash Smith's understated phrase, "a relatively neutral field of study" (31).

That this was the right tack was obvious to Matthiessen when he observed the scope of destruction as he made his way to Salzburg through Germany, making Frankfurt one of his first stops. Not incidentally, the object of his interest was the Goethe house, laid to waste by the allied air-raids (Matthiessen would go on to note that some of it might have been excessive) to a degree that left him shocked. Certainly, the building stood as a gauge for the state of affairs across Germany and the rest of the countries where he travelled. The U.S. personnel in Germany were, in another telling reversal, "the civil servants of the new American empire" (8). In an important sense, Matthiessen as traveler re-enacts Emerson's grand tour of Europe at the age of 29; except that now it is the American that carries cultural distinction to bestow it on the old continent (23). To propose another fitting literary parallel, Matthiessen might have felt not a little like Henry James—himself a subject of the critic's interest—or Jamesian characters who came to Europe to gain a new taste of life. "Might" is a key word here since in "The Responsibilities of the Critic" Matthiessen plays upon this eternal theme, "the wide gap which still exists between America and Europe," which was then distilled by Henry James into "his leading theme in the contrast between American innocence and European experience" (109). However, the experience offers a poignant lesson indeed. Further travel through the country, leading him to Munich and thence to Salzburg, makes evident the extent of destruction, while the surreal effects are compounded by the adjacency of Schloss Leopoldskron, where the seminar is to take place, to a D.P. camp. (During his later visit to Munich, Matthiessen comments on the loss and destruction as a "waste land produced only by our time" [37].)

In the new dispensation, it is the Harvard graduates of European/ Jewish descent that transfer by way of the pedagogy of American Studies the notion of American civilization to the scarred continent (10). The complex of American values, compressed into "culture and humanism," is now seen as a buffer against the barbarism to which

\footnotetext{
Noting the landmark status of Matthiessen's travelogue, Gross offers a quote that clinches the argument condensed in the Salzburg Seminar and in American Studies as a whole at the time, which Matthiessen critically re-examined through his "dissident internationalism" (75). The quote reads: "Europe is no longer regarded as a sanctuary; it no longer assures that rich experience of culture which inspired and justified a criticism of American life. The wheel has come full circle, and now America has become the protector of western civilization, at least in a military and economic sense" (qtd. in Gross 73).
} 
Europe sank in the war (13). This is already a program for American Studies in the making, an agenda, thus, that burgeoned away from the halls of academe (hardly the case with the classical and aloof American Renaissance model) and amidst the practical and immediate concerns in the field, so much so that Matthiessen is excited by the "historic occasion" offered him (13). This section already contains ingredients for a wholesale American Studies project: besides the self-congratulatory flair, there is a conviction that America should serve as a role-model for Europe, Matthiessen suggests, in that it is already a multiethnic nation $(14,192)$.

The other distinction that Matthiessen's version of American Studies contained and disseminated will only considerably later become a key fault line in the discipline, as documented by Pfister in his outline of American cultural studies (Pfister). The concept of American civilization with which Matthiessen and other instructors operated in the seminar sessions, however, is removed from the more visible and accessible appurtenances of the pop and commodity culture already overflowing the occupied Europe (the Coke logo, ice-cream), so that already there is a contention between different concepts of culture that should be incorporated into a program of cultural recovery. Unlike his successors, Matthiessen was clear on this point: the hierarchy of cultural products was crystalized in a moment of critical inspiration that he had previously elevated and turned into the canon; what remained was to flank the pantheon put forth in his groundbreaking study with an assortment of more contemporary authors (James, Dreiser, Dos Passos, Steinbeck, Hemingway, Elliot and Cummings [2829]). According to Gross, he espouses "a transformational aesthetic that places art at the center of politics" (84), even though it is specifically the high art requirement that in retrospect would prove the least compelling for his intellectual heirs.

Depressed and disheartened, deprived and hungry, the students in the seminar are a diverse lot, sharing a sense of being "debilitated" by war (59). The archives of the 1947 seminar offer a glimpse of the participant list, which included mostly Westerners, with only Czechs and Hungarians in attendance from Eastern Europe (it is to be understood that this absence was not due to the organizers' partiality but because of already evinced political tensions ["Salzburg," p. 3]). While the keen and energetic Harvard student organizers set down to implement their idea, a more cautious report warns that "the intellectual and social challenge" of the seminar might be "underestimated by the Americans" ("Salzburg," p. 24) thus reflecting the varying levels of idealism (or political realism).

Matthiessen briefly stated his interest and provided an outline of the literary section of the curriculum, which he shared that year with Alfred Kazin (American literature) and Vida Ginsberg (American drama) ("Salzburg," p. 2). In this roster of writers, we shall focus for the moment on Herman Melville in order to tease out the implication that his work had for Matthiessen's sense of his critical and social mis-

10 Since my interest is not primarily in American Renaissance, except as a solid background against which Matthiessen's 1947 seminar would proceed, here I will further reference only Grossman's remark, which proposes that, in his classic study, Matthiessen overlays his literary criticism with autobiography (49). 
sion. Matthiessen's abiding interest in Melville, as Grossman points out, allows us to utilize Melville's work to understand Matthiessen, as well as his critical procedure. ${ }^{10}$ In his brief excursus, Matthiessen notes how his perspective on Moby-Dick has changed somewhat in the intervening period (since his American Renaissance) allowing him to rescue the scenes from the novel that eluded him back home and evacuating Melville from Emerson's embrace, thus straining towards a new reading of the novel, precisely the one that would be taken up and accomplished by C. L. R. James: "I found a new clue to his [Melville's] own creative intention"; "Such reflections on the lack of superiority owing to race's whiteness occur more often in Moby-Dick than I had remembered"; "No more challenging counterstatement to Emerson's self-reliance has yet been written" $(35,36,37)$.

His special vantage point, which Gross handily dubs "dissident internationalism ... compatible with situational approach" (75), allows for more synthetic remarks on a number of issues, from the state of American higher education, the notion of an ideal university, to the complex set of relations between a mass democratic society and its technologized, mass produced and consumed art, from the disquisitions on the Soviet and American revolutions, to a section detailing his political education that proceeds hand in hand with his academic path (75). Matthiessen is clearly torn between the realities of the two available political alternatives (American and Soviet), and, internally, he is at pains as to where to place himself in the moving picture: he is a socialist, but pointedly not a communist (even if he made the distinction, the public in late 1940s United States would no longer care to do so). The blurring political affiliations that Matthiessen describes here were essentially part of the New Deal coalition that emerged in the 1930s and 1940s but were becoming dysfunctional or reconfigured in the new period, which Matthiessen found hard to brook. Part of his reluctance to join the communists might have been caused by his deep Christian convictions (82). Another speculation is provided by Fuller, who notes Matthiessen's ominous silence about his 1930s visit to the Soviet Union, of which there is almost no record in his otherwise comprehensive and meticulous correspondence (91).

In October and November of 1947, upon the completion of the Salzburg seminar session, Matthiessen proceeded to Prague for the inaugural lecture in American Studies at Charles University. This section, and its follow-up in Hungary, are interesting also from a purely historical perspective, since they allow for a short-lived glimpse, an embodiment of, what Matthiessen hoped would be the third way. At the time, Czechoslovakia was a country poised between East and West (105): it had a multiparty government, in which communists shared power with other parties. In ethnographic terms, Matthiessen figures in this part of the text more as a "participant observer," a position of relative authority which, however, must rely to some extent on "native informants" that mediate the context for the narrator (for these terms cf. Clifford). The hovering question about the viability of the third way underscored by the apprehension of Russian interference (128) are all filtered through his guides from different social and political circumstances (mostly, it is Jan, a seminar participant and a young Czech communist who provides the context). The text uncannily registers, al- 
most in real time, the creeping effect of the onset of the Cold War. Not even a pastoral scene in the Czech countryside can break the spell of gloom and anxious anticipation spreading over the country. ${ }^{11}$

History caught up with the text, since by the time of the publication Matthiessen was obliged to gloss it with the developments in the wake of the Soviet coup in February 1948 (143). The gloss, which hardly does justice to the gravity of the situation, did not do service to Matthiessen's political acuity either, nor did it endear him to his academic and political adversaries while it intensified the criticism of the previously exalted founding father (Fuller 98; Pease 1996: 32-33). The text tried to maintain a balance to the very end, even when politically it became impossible to steer a neutral course between the countries that in a short while would embrace the Marshall Plan and those that refused or were made to refuse the United States' offer (144). What is to some extent astounding is Matthiessen's lack of critical appreciation of the Soviet tactics in its professed sphere of influence in the early days of the Cold War-and this underappreciation will be especially felt in the final stage of his itinerary.

Another country whose status wavered was Hungary, where Matthiessen proceeded from Czechoslovakia (this was still in the period before the coup). In Hungary, the communists were one of the minority parties but were bolstered by the excessive Russian military presence (157). More so than Prague, the atmosphere in Budapest exuded a fear of Russians. That the party could show appreciation of the local context was evident in a complimentary and rather positive review of the seminar session that had previously been published in New Hungary, a leading communist weekly in Hungary. The piece, dated 20 September 1947, begrudgingly admitted the humanitarian and scholarly values of the American endeavor, principally since it shied away from American ideology, was enthusiastically received, and widely circulated in the post-seminar evaluations and reports ("Salzburg," pp. 31-32). It looked like the next year might bring more Eastern Europeans, but only for a short while. Even here Matthiessen comes off as well-meaning, engaged, and perceptive but constrained by his outsider status. The Hungarian story, too, has its installment as Joe, his Hungarian guide, was forced into exile to the States in a short while.

The final reduction in perspective shown in the narrator's loss of authority that serves as an ironic interlude to the reception of the text is quite the opposite of the ebullient opening of the travelogue, where Matthiessen saw his return to Europe as a way to displace himself and so allow for a clearer image of himself as an American (3). The vision that emerged in sharper perspective is that of American civilization, which towers over the drab and tattered European scene, providing an American scholar with an appropriate stage for his own critical and humanistic performance. If only by coming to Europe Matthiessen was able to "think about" what "it means to be an American today" (3), then it follows that From the Heart of Europe is a necessary appendix, a coda for the diptych whose first section is American Renaissance. Fantasmati-

For more on the Czechoslovak situation at the time, cf. Myant. 
cally, the Matthiessen of the first, classical study comes into his own only by acting out the role that he first envisioned as an American Renaissance scholar now mounting the truly international scene. From the Heart of Europe thus provided a point of emergence for the exemplary American scholar in the twentieth century, a role begun by Matthiessen and followed up by a long list of his successors both in Salzburg and other American Studies programs. The ultimately auspicious conjunction marked for the next several decades (until 1989) both the limits and the possibilities of doing American Studies. Matthiessen's Central and Eastern European episode thus proved germinal and sustaining for American Studies overall.

Certainly, this is a more optimistic reading. The less cheery would be that, for Matthiessen at least, this book marked the end point of his journey as a critic and a scholar who held "responsibilities" for the world he lived in, after which he could only plunge into nothingness (193). However, his individual tragic fate was, paradoxically, an indication of the viability and appeal of his model of doing American Studies scholarship for decades to come: like Moses, he led his followers to the boundary of the promised land that he was forbidden to enter himself. Such a reading that posits a truly generative potential of his critical performance is sustained, among others, by the example of the second generation of American Studies scholars, Matthiessen's disciples who carried on the torch. The concluding pall of despair descending on Matthiessen's vision could easily be depoliticized and ascribed to his personal plight, or it could be displaced by a collective act of disavowal by the American Studies community until a fairly recent rediscovery of From the Heart of Europe floated in on a revisionist surf.

\section{Transnational American Studies Before Its Time}

In the second part of my essay, I will propose several assumptions concerning C. L. R. James's text Mariners, Renegades and Castaways, which, like Matthiessen's, was written at a time (1953) when intellectual pursuit was tethered to a single-minded political purpose, but with a slightly different spin. It is this decentering move that makes James's ruminations (ostensibly on Herman Melville's novel Moby-Dick, but more viscerally on his own situation at the time) an apt, occasionally indirectly subversive commentary on Matthiessen's thoughts and observations. Additionally, I would like to argue that James's ironic footnoting of Matthiessen (in a general sense of the attitude that his text projects), becomes possible because James was already offcenter, in ways that Matthiessen could not be-James was imagining a space for himself, and in extension for his version of American Studies, that was refracted through his position as a non-native, alien (in the sense of lacking citizenship), black, and engaged leftist intellectual. The Melville envisaged by Matthiessen in American Renaissance already showed the split from the image of the writer in Matthiessen's Salzburg and Central European lectures which then further intensified in James's study of him, for reasons that I will try to point out further on. At this point I will simply state that this floating vision of Melville as presented by the two scholars stands for an alterna- 
tive vision of America and American Studies that did not take root at the time and is only recently being restored. ${ }^{12}$

Let me add that placing James in the context of an American Studies debate is by no means an endorsed critical method; rather, it is more of an exception. Indeed, most studies of the critic so far rightly place him within the context of the international left around the World War; alternatively, he is considered in the context of anticolonial struggles and postcolonial issues in the latter half of the twentieth century. ${ }^{13} \mathrm{It}$ was only fairly recently that Donald Pease made a cogent claim for situating James, and this text in particular, as an important link in the emergence of "a transnational America(s) study" (2002: 153). Yet, as the editors of his unfinished manuscript now available as a book, American Civilization, point out, even if James was an emigrant in Europe (England) from his native Trinidad for a number of years before coming to the United States, it was his experience there that profoundly shaped the thought and political philosophy that he would espouse in his writings. James's intense observation of American society and its ways, indeed his impulse to call it "civilization," testified to an intense intellectual stimulation that he got from the American scene (Grimshaw and Hart 13,14). It is with these facts in mind that a more comprehensive view of James's contribution to American Studies becomes possible, such that is only beginning to be articulated (cf. Jelly-Shapiro).

Locations marking the birthing pains of American Studies are indeed surprising, if we consider not only the waystations of Matthiessen's Central European voyage in 1947, but also as we turn our attention to the scene of emergence of James's legendary appraisal of Melville-the book was mostly written during 1952 at the Ellis Island detention center where James, interned for months, awaited hearing in his deportation case. ${ }^{14}$ During that time, Pease suggests, James effectively existed in "the state of

12 Since my interest is primarily in considering an aspect of James's participating in and generating a version of American Studies (even if only hypothetically), in this section I am indebted to several of Pease's recent textual engagements with James's newly recovered legacy for American Studies; cf. Pease 2001; Pease 2002. Another important source for this aspect of James's work is the critical edition of his American Civilization, an unpublished and incomplete manuscript prepared for publication in 1993 by Anna Grimshaw and Keith Hart.

13 Exemplary in this respect is Grant Farred's study devoting a chapter to James and placing him squarely in the Caribbean, pan-African, and anti- and post-colonial contexts. As such, Farred attests to "James's proclivities for the margins of the political left" and further alludes to his work "at a remove and an odd angle from dominant left political thinking" boosting his "prescient and deft ... reading of anticolonial resistance" (100).

14 At this point it is worth reconstructing in brief James's movements at the time. In 1938 he arrived in the States from England on a visitor's visa with the purpose of lecturing throughout the country. This brief visit, however, extended to the next ten years. As Grimshaw and Hart point out, "Never having acquired a resident immigrant visa, James was served with a deportation order by the ... INS in 1948. After two years of legal hearings before the INS, the order for his deportation was upheld" (15). Further information on James's legal status can be gleaned from Pease's informative introduction to Mariners, where Pease claims that James did pass citizenship eligibility requirements and was waiting for the government's decision in 
exception" and, as an "illegal alien," was disabled from giving testimony on his own behalf (2001: xxv). He did, however, have the right to an attorney. Given the mythic role of Ellis Island as a port of entry for millions of transatlantic emigrants, it is with irony that we note James's predicament as a "subversive" intellectual targeted by McCarthy's red-baiting on the strength of the McCarran-Walter Act of 1952.

Much like Matthiessen's idiosyncratic, urgent, and irrepressibly "private" intellectual testament, James's work is also occluded in the archive of the discipline. According to Donald Pease, even in 2000 it was the case that James's study was at best marginal in the Melville canon, if referenced at all (2002: 1). Pease quotes further a scholar who faults James's approach to Melville's classic Moby-Dick as "his vivid reimagination of it [the novel]" rather than a straightforward critical engagement (Cain, qtd. in Pease 2002: 2). The paradigmatic import accorded to Moby-Dick is another shared feature by the two authors thus reiterating Matthiessen's inaugural gesture of establishing a national literary canon. Still, it is also the case that both our authors then make the novel signify their pressing private and public concerns at the time as they turn it into a potent cipher in the long line of its interpreters. Being established as one of the key texts in the national canon, Moby-Dick presents an interpretative challenge for each new generation of critics, which is compelled, in Pease's words, "to designate ... the terms in which a text must be read in order to maintain cultural power" (1985: 113). In retrospect, James's study of Moby-Dick "announced his intellectual independence," in the words of his literary executor (Hill 321).

However, there is additionally a political ground from which James's book was considered unorthodox, in particular for international leftist critics, as Pease makes clear in his informative introduction to the recent critical edition of the Melville study. The problem for most left-leaning critics occurs in chapter VII of the textJames's extraordinary but justified breach of academic decorum—where he fractures the critical illusion of objectivity and aloofness, and dramatically reaches out to the reader in order to appeal his own case. His autobiographical story completely overshadows - but strangely enough, also bolsters - the critical claims he has put forth previously about Melville's novel, its crew, mission and particularly its captain, Ahab. In the final part of his study-that even before was recalcitrant to the mores of disinterested critical discourse- the divide between the public and the private breaks down as James protests his placement "in the cell reserved for Communist detainees" (Pease 2001: xx; James 126). ${ }^{15}$ Arguably, he does this for several reasons, the practical one being that, should he be classified as a communist (which he was not), this would further reduce his chances of obtaining a hearing, let alone citizenship. A more com-

\footnotetext{
his case when, at the height of the Red Scare, the McCarran-Walter Act was passed. Pease further argues that, retroactively applied to James, the provisions of this act made James's position in the hearings untenable. In the last stage of his case, James was arrested in 1952 and detained for four months before being deported in 1953.

15 All subsequent references to the text of Mariners, Renegades and Castaways will be provided parenethetically in the text.
} 
plicated reason, however, is James's own displeasure with the false designation placing him in the same camp with the then dominant Stalinist vein of communism, to which James was vigorously opposed (Pease 2002: xx, viii; James 154). I insist on these hairsplitting distinctions because they preordained every aspect of the production, circulation, and reception of both texts at the time, not to mention the fates of their respective authors (fatally for Matthiessen, less so for James). James's political disaffiliation from extant categories rendered him not only subversive for the U.S. government, but also unassimilable even for the later leftist criticism which silently passed over his denunciation of communism in chapter VII (or boycotted the book in its entirety). Given the book's liminal status until fairly recently, however, we see that James's position at the time did not quite authorize him, as it did Matthiessen (in Arac's apt term [Arac]), to create a "scene of cultural persuasion" that would set up a new context in which to understand the novel within a new geopolitical setting (Pease 1985: 113).

Some readers objected to James's personalized and slanted reading as he suggestively connected the two layers: the actual scene on the deck of the whaler Pequod and his agonistic stance to both "the national security state" (Pease 2002) and the absolutist logic of communism. Based on Melville's characters, James draws an incisive psychological portrait of a revolutionary communist, who in his zeal to precipitate an upheaval exhibits single-mindedness, devotion, and obsession even while initially masking his real object akin to Ahab's fatal and irrevocable resolve (and his initial dissimulation) (132). The most dismissive argument pointed at James's narrow political scope in his unequivocal denunciation of communist totalitarianism, since by articulating it and then circulating the book among the members of Congress, he evidently tried to bolster his case (Jelly-Shapiro 54), even as it conveniently disregarded the early textual evidence underlying James's logic. In the early chapters, James laid the ground for his argument that industrial civilization (fueled by capitalism and then simply taken over by socialist state bureaucracies) bred the totalitarian type, like Ahab, willing to submit both nature and his fellow men to his single-minded and destructive purpose (45).

The scene of writing for James predetermines the kind of displaced, autobiographical and political reading that he is to create in Mariners, Renegades and Castaways. As he was contemplating this book, he "was arrested by the United States government and sent to Ellis Island to be deported" (125), so that his tenuous civic status becomes the tenor of the book, which, according to critics, rightly causes him to shift his attention from the usual suspects, either the sailor Ishmael or the captain Ahab, to the crew itself: "It seems now as if destiny had taken a hand to give me a unique opportunity to test my ideas of this great American writer" (126). The complex identifications that Matthiessen managed to keep at bay (only to have them articulated in his non-critical, occasional writing) become for James a generative principle of his reading of Melville ready to erupt at the end of his text. Life breaks into the book as "my experience" becomes James's way-the only possible under the circumstancesto interpret Melville's vision for the nation in the present time (125). Earlier, I provided a cogent explanation for the centrality of Moby-Dick in the American canon, a 
process long in the making since, as Pease contends, it took precisely the conditions ushered in by WW II and then the Cold War to establish the novel as a diagnostic text (2001: xxix). Consequently, the Ellis Island detention center is the Pequod; the detainees, including James, are the ship's crew: "The Island, like Melville's Pequod, is a miniature of all the nations of the world and all the sections of society"; "a thousand men, sailors, 'isolatoes,' renegades and castaways from all parts of the world" $(3,126)$. The context of the text's production provides "the most realistic commentary" on Melville and his vision (125).

That James would begin with Melville, and Moby-Dick at that, goes without saying, since it was a choice that lent itself to him as he researched American popular culture, which Melville was very much a part of (3). This is certainly not all the result of a "shock of recognition" between the long dead author and contemporary Americans, but the outcome of several happy coincidences. One of them was the Melville revival going on for some time among the critics, who used him in order to bolster the case of American literature as a subject in its own right; it was this critical campaign that would feed, among others, Matthiessen's canon construction. Secondly, this belated recognition suggested that Melville was in advance of his time and that it took twentieth-century consciousness to rescue his texts from oblivion as a document relevant for the contemporary moment. James's engagement thus reflects the last stage of Melville's rising critical fortunes (124).

Had he remained with the insight inspiring his praise of Melville and his immense curiosity about the American civilization (160), this would still be a valuable but just one in a long line of high appraisals of Melville and Moby-Dick. But notwithstanding the previous political enframing of the study, or the deep and poignant personal inspiration causing James to virtually identify with Melville's mariners, the book still offered a peculiar Jamesian perspective that was hard to pin down to categories, political or otherwise. More than that, however, James made an urgent critical choice of disassociating the novel from the Cold War narrative to which it had been made to comply (Pease 2002: 137), and instead reoriented the text towards a hemispheric, if not even, in current parlance, transnational context on one hand and on the other "a juridical appeal" on his and the detainees' behalf (Pease 2002: 138).

James's reading of the novel interweaves different time planes, the past refracted through Melville's vision, the present of James's detention, and the global present coalesced into the competition of the two super-powers occasionally inching towards the threat of nuclear annihilation. For James at the time, it took no great leap of imagination to see the unravelling of Moby-Dick's plot as an uncanny comment on the then current global situation (115). Ahab, the unlikely Quaker and captain of the whaler Pequod, bound to sea presumably in pursuit of the lucrative sperm oil, in fact harbors a different purpose- that of hunting down and killing his arch adversary, who had once maimed and almost killed him - the legendary white whale by the name of Moby Dick. (On Melville's sources for Moby-Dick, cf. Philbrick.) James aligns with most extant readings that assign to Ahab a preternatural will, a tyrannical sway over the crew that exceeds simply his prerogatives as a captain but has to do with 
his Manichean disposition. Where he departs from them, however, is that he places the characters squarely in the present, so that Abah becomes a "totalitarian type" (9), a worshipper of fire, which signals technology, progress, and mastery over arts and sciences (10). Ahab, along the lines of Hitler and Stalin, then uses science and politics in order to keep his absolute control over the ship and his crew (15). Furthermore, as "a dictatorial personality" (15) he evinces his loathing of the men under his command, citing their sordidness and their being "manufactured men" (16). This is an insightful and straightforward denunciation of a character who had usually been vindicated by the critics for his inveterate individualism, his mythic qualities, and the nobility of his purpose (so unlike the paltry or profit-minded interests of the crew and the owners of the ship).

Ishmael's character undergoes the similar twist of interpretation. According to James, Ishmael, one of the crew members and technically a narrator of the story, "wavers constantly between totalitarianism and the crew" (40). The blankness which envelopes Ahab is reciprocated by the spleen that haunts Ishmael, who therefore follows Ahab together with the rest of the crew, i.e., as if spellbound or against their rational will. James is especially concerned with showing how a totalitarian mind exerts its influence even on seemingly critical and restrained people, as is Ishmael at the beginning. A disaffected young man, sensitive and melancholic (an intellectual type, one might add), he befriended the harpooner Queequeg, but once on the ship together with the rest, he succumbs to Ahab's monomania (43). James further insists that Ishmael's breakdown, the surrender of his will to that of Ahab's mad and destructive purpose, happens in one of the so-called industrial sections of the novel, the try-works chapter that presents the process of extracting the precious sperm oil from the sperm whale's blubber, thus turning the ship into a veritable factory (for a historical context of whaling, cf. Philbrick 1-27; cf. ch. 96 of Moby-Dick). This is an interesting extension of Melville's vision that James takes to new heights. It is here that James locates what he deemed "the question ... at the heart of the civilization process itself-the relationship between individual freedom and social life" (Grimshaw and Hart 14). Oftentimes this question was posed as the issue of labor in an industrial and mechanized context, as was the case with the whaling industry in the early nineteenth century. The relentless logic of the extraction of labor sucks in not only the ship's crew, but also the reluctant Ishmael, who succumbs to "the industrial tyranny of American capitalism" (Grimshaw and Hart 12). According to Hill, "Fearful or fanatical, the intellectual becomes in James's perspective a necessary partner of the totalitarian bureaucracies of the twentieth-century" (363). Such a reading clearly took the novel away from its earlier myth-and-symbol concerns into the direction of pressing contemporary issues that Melville had presciently articulated. It also for the first time signaled Ishmael as a negative center of gravity, alongside Ahab, a reading that would become possible only in the revisionist stage of the criticism of the novel (and as such articulated anew by Pease in his 1985 contribution).

Midway into his argument about Melville's novel, James further opens his cards by posing as key questions the following: why didn't the men revolt? Why were the 
officers on the ship unable to stand up to Ahab? Why does the first mate Starbuck, even at the turning point in the plot, pass up a chance to kill Ahab? The crew is immobilized and incapable of acting at the diegetic level, but what Melville certainly wanted to set it into relief is evidenced by an upheaval that happened at the metadiegetic level, as a story-within-the-story (principally the Town-Ho mutiny, which exists only as a framed story in ch. 54 of Moby-Dick). It is at this point, where he is still ostensibly reading Melville but is already casting about for ways to interpose his present-day concerns, that James articulates Melville's principal theme: "how the society of free individualism would give birth to totalitarianism and be unable to defend itself against it" (54). James had ample evidence around him suggesting that one of the springs of totalitarianism lay in the phenomenal rise of a new industrial civilization, the mechanical age, and the event of the global war.

It is from this moment on that the splitting, a key structural impulse of James's reading, occurs, as Pease contends, and continues to inform the text to its end (2002: 157). The splitting was also Matthiessen's strategic way of negotiating the impossible contrarieties that a Cold War field imaginary of American Studies had precluded for the time being and that simultaneously subordinated all his critical efforts. Matthiessen, however, for the most part managed to keep the process of splitting away from and outside his critical texts; this comes to the fore in his autobiographical and marginal From the Heart of Europe. James, however, places the splitting demanded for his own inclusion in the American polity, and his work into the Cold War American Studies field imaginary, at the center of his work. If we follow the aforementioned analogy proposed by James - that Ellis Island is the Pequod, and the detainees (including James) are the crew (126) — than we should observe why the detainees don't mutiny against their oppressive conditions. The most obvious reading would indicate that, since it is the state that detains the subversives (the "mariners, renegades and castaways" from James's title), it then proceeds that the American state apparatus exercises the Ahabian totalitarian will. At this point we should go back to James's early and trenchant denunciation of the McCarran Immigration Bill of 1952, which, retroactively applied in his case, trampled on his rights and, moreover, according to James, smacked of "racial superiority" (13). This would seem a logical and disturbing application of Melville's vision to early Cold War America, where James had enough evidence to illustrate the intimidating and excessive actions by the F.B.I. and the Department of Immigration.

However, the story in the internment center goes on. It seems that there are some people there looking for ways to fight the detainment, namely, the communists. The way James treats them is inextricably linked to his previously laid out scene of reading the novel. The terms he uses to describe the communist detainees are indicative: "Communists were men of purpose" (127); they were an Ahab-like force (ibid.). There is especially an anonymous communist detainee that engrosses James's attention and, by his strong and interfering personality, becomes a fixture on the island. James is therefore observing him and gathering evidence of his Ahabism (132). It seems that for James the novel seeps into life, not only by referencing his own situa- 
tion but by offering a cast of characters in a drama involving the entire world as shown by the international cast of the detainees (151). The insider knowledge (James reiterated that he "knew all about" communists [126]) is not only based on the analogies from Moby-Dick but is corroborated by James's years of activism and campaigning on the left, both in Britain and the United States. His literary metaphor is extended in the afterword added in the 1978 edition that roundly condemns the excesses of world communism coming to light especially after the open denunciation of Stalin in 1956 and the revelation of the Gulag camp system (172-73). His critique of both the Ahabism of the "national security state" and of the equally menacing Ahabism of its ideological opponent (communism/Stalinism) made C. L. R. James a persona non grata in the United States soon afterwards, while it for decades prevented and precluded his unequivocal inclusion into the critical archive of American Studies. That some of the most recent revisionary moves have rescued the text from neglect and offered a new take on the well-known past testifies to the vitality and resilience of the disciplinary practice.

\section{Conclusion}

If "the arena for cultural discussion provided by the Cold War," as Pease suggests, was "crucial" for the self-recognition of American Studies (1985: 113), then it also proceeds that it rather predetermined and curtailed the parameters of discussion thus causing some of the most striking participants—such as F.O. Matthiessen and C.L.R. James - to find themselves barred from or sidelined in the exchange. It is with each retrieval of the "scene of cultural persuasion" in which a literary and a critical text equally participate that we as critics and scholars should endeavor to make legible and visible the current and past logic of "cultural persuasion" that permeates and enlivens the discipline.

I would like to recapitulate this dazzling (or vertiginous, as the case may be) journey of American Studies into its past by evoking Thomas Kuhn's influential model of the change of scientific paradigms, in which he postulates a dynamics of change- - this does not happen by accretion, Kuhn asserts, but rather by a full displacement of the previous model by a more recent and apposite one (1-9). While this indeed holds true for the hard sciences, it is inadequate, as I hope my discussion has shown, to account for the vicissitudes of humanistic inquiry, which for better or worse always folds back on itself, committed to endlessly converting its own past into history and retrieving the seemingly lost or forgotten pieces only to make them reappear again. This episode from the early Cold War moment of American Studies, all the more pregnant since it marked the birth and institutionalization of the critical practice, is no exception to this endless drive. 


\section{Works Cited}

Arac, Jonathan. "F.O. Matthiessen: Authorizing an American Renaissance." Benn Michaels and Pease, pp. 90-112.

Benn Michaels, Walter, and Donald E. Pease, editors. The American Renaissance Reconsidered. The Johns Hopkins UP, 1985.

Cheyfitz, Eric. "Matthiessen's American Renaissance: Circumscribing the Revolution." American Quarterly, vol. 41, no. 2, 1989, pp. 341-61.

Churchill, Winston. "The Sinews of Peace Speech." 1946. Churchill, www.winstonchurchill.org. Accessed 10 Feb. 2016.

Clifford, James. The Predicament of Culture: Twentieth-Century Ethnography, Literature, and Art. Harvard UP, 1988.

Farred, Grant. What's My Name: Black Vernacular Intellectuals. U of Minnesota P, 2003.

Grgas, Stipe. "American Studies and the Canonization of Thomas Pynchon." Borderlands, vol. 2, 2013, pp. 17-26. serbianamericanstudies.rs/wp-content/uploads/2013/04/BORDERLANDS-2013-final.pdf.

— . "American Studies as a Contemporary Disciplinary Practice." Sic-journal, vol. 4, no. 2, 2014. hrcak.srce.hr/sic, doi: 10.15291/SIC/2.4.HUAMS.3.

- Američki studiji danas: identitet, kapital, spacijalnost. Zagreb, Meandar, 2015a.

- . "Croatian Leftist Critique and the Object of American Studies." Working Papers in American Studies, Vol. 1. Edited by Jelena Šesnić and Sven Cvek. Croatian Association for American Studies, Zagreb, 2015b, pp. 83-114, www.huams.hr/ wpas.

Grimshaw, Anna, and Keith Hart. "American Civilization: An Introduction.” James 1993, pp. 1-25.

Gross, Andrew S. "'Death Is so Permanent. Drive Carefully.': European Ruins and American Studies Circa 1948." Re-Framing the Transnational Turn in American Studies. Edited by Winfried Fluck, Donald E. Pease, and John Carlos Rowe. Dartmouth College P, 2011, pp. 72-96.

Grossman, Jay. “'Autobiography Even in the Loose Sense': F.O. Matthiessen and Melville." Leviathan, vol. 13, no. 1, 2011, pp. 45-57.

Hill, Robert A. "Literary Executor's Afterward." James 1993, pp. 293-366.

James, C.L.R. American Civilization. Edited and introduced by Anna Grimshaw and Keith Hart. With an Afterword by Robert A. Hill. Blackwell, 1993.

-. Mariners, Renegades and Castaways: The Story of Herman Melville and the World We Live In. 1953. With an Introduction by Donald E. Pease. Dartmouth College P, 2001.

Jelly-Shapiro, Joshua. "C.L.R. James in America, or, the Ballad of Nello and Connie." Transition, no. 104, 2011, pp. 30-57.

Kuhn, Thomas S. The Structure of Scientific Revolutions. 1962. $2^{\text {nd }}$ ed, enlarged. International Encyclopedia of Unified Science. The U of Chicago P, 1970. 
Lazo, Rodrigo. "Migrant Archives: New Routes In and Out of American Studies." States of Emergency: The Object of American Studies. Edited by Russ Castronovo and Susan Gillman. The U of North Carolina P, 2009, pp. 36-54.

Levin, Harry. "Some European Views of Contemporary American Literature." American Quarterly, vol. 1, no. 3, 1949, pp. 264-79.

Marx, Leo. "On Recovering the 'Ur' Theory of American Studies." American Literary History, vol. 17, no. 1, 2005, pp. 118-34.

Matthiessen, F.O. From the Heart of Europe. Oxford UP, 1948.

- . "The Responsibilities of the Critic." 1949. Speaking of Writing: Selected Hopwood Lectures. Edited and with an Introduction by Nicholas Delbanco. U of Michigan P, 1990, pp. 101-14.

Melville, Herman. Moby-Dick; or, The Whale. A Norton Critical Edition. Edited by Harrison Hayford and Hershel Parker. Norton, 1967.

Myant, M. R. Socialism and Democracy in Czechoslovakia, 1945-1948. Cambridge UP, 1981.

Smith, Henry Nash. "The Salzburg Seminar." American Quarterly, vol. 1, no. 1, 1949, pp. 30-37.

Pease, Donald E. "Moby-Dick and the Cold War." Benn Michaels and Pease, pp 113-55.

— . "New Americanists: Revisionist Interventions into the Canon." boundary 2, vol. 17, no. 1, 1990, pp. 1-37.

- . "Negative Interpellations: From Oklahoma City to the Trilling-Matthiessen Transmission." boundary 2, vol 23, no. 1, 1996, pp. 1-33.

— . "Introduction." James 2001, pp. vii-xxxiii.

—. "C.L.R. James, Moby-Dick, and the Emergence of Transnational American Studies." The Futures of American Studies. Edited by Pease and Robyn Wiegman. Duke UP, 2002, pp. 135-63.

Pfister, Joel. Critique for What? Cultural Studies, American Studies, Left Studies. Paradigm Publishers, 2006.

Philbrick, Nathaniel. In the Heart of the Sea: The Tragedy of the Whaleship Essex. Viking, 2000.

Redding, Arthur. Turncoats, Traitors, and Fellow Travelers: Culture and Politics of the Early Cold War. UP of Mississippi, 2008.

"Salzburg Seminar in American Civilization." Salzburg Seminar, 1947.

Truman, Harry S. "Annual Message to the Congress on the State of the Union." January 8, 1951. Online by Gerhard Peters and John T. Woolley, The American Presidency Project. Accessed 10 Feb. 2016.

Wald, Allan. American Night: The Literary Left in the Era of the Cold War. The U of North Carolina P, 2012.

Wegner, Phillip E. Life between Two Deaths, 1989-2001: U.S. Culture in the Long Nineties. Duke UP, 2009. 